\title{
İlk ve Acil Yardım Öğrencilerinin Kadına Yönelik Şiddete ve Şiddette Mesleki Rollerine İlişsin Tutumları
}

\section{Attitudes of First Aid and Emergency Aid Students Regarding Violence Against Women and Their Professional Roles in Violence}

\author{
Ezgi Şahin ${ }^{1}$ (D) İlkay Güngör Satılmış ${ }^{2}$ (iD \\ ${ }^{1}$ İstanbul Üniversitesi Cerrahpaşa Lisansüstü Eğitim Enstitüsü, Kadın Sağlığı ve Hastalıkları Hemşireliği Anabilim Dalı, İstanbul, TÜRKIYE \\ ${ }^{2}$ İstanbul Üniversitesi-Cerrahpaşa Florence Nightingale Hemşirelik Fakültesi, Kadın Sağlığı ve Hastalıkları Hemşireliği Anabilim Dalı, İstanbul, \\ TÜRKIYE \\ Geliş tarihi/ Date of receipt: 27/08/2020 Kabul tarihi/ Date of acceptance: 23/09/2020 \\ (C) Ordu University Faculty of Health Sciences, Department of Nursing, TURKEY, Published online 30/09/2020
}

\section{ÖZ}

Amaç: Araştırma ilk ve acil yardım öğrencilerinin kadına yönelik şiddet ve şiddette mesleki rollerine ilişkin tutumlarını ve etkileyen faktörleri belirlemek amaciyla yapıldı.

Yöntem: Kesitsel olarak yapılan araştırmanın örneklemini Arel Üniversitesi İlk ve Acil Yardım Programında okuyan ve çalışmayı kabul eden 240 öğrenci oluşturdu. Veriler; Demografik Bilgi Formu, Şiddete İlişkin Tutum Ölçeği ve Sağlık Personelinin Şiddette Mesleki Rollerine İlişkin Tutum Ölçeği ile toplanmıştır. Veriler; yüzdelik, sayı, ortalama, student t testi, tek yönlü varyans analizi (ANOVA), Kruskal-Wallis, Mann Whitney U ve post hoc test/ tamhane testleriyle değerlendirildi.

Bulgular: Kız öğrenciler ve baba eğitim düzeyi lise ve üzeri olanlar şiddete karşı geleneksel tutum gösterdikleri bulunmuştır $(\mathrm{p}<0.05)$. Öğrencilerin cinsiyet ile şiddete ilişkin eğitim alma isteği arasında $(p=0.003)$ ve cinsiyet ile bildirim yapma arasında istatistiksel olarak anlamlı bir fark bulunmuştur $(\mathrm{p}=0.024)$. Öğrencilerin şiddete ilişkin tutum ölçeği genel puan ortalamas1

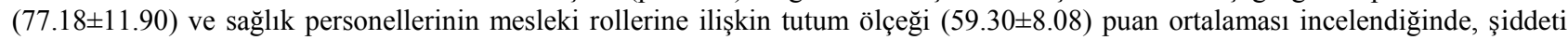
normalleştiren geleneksel bakış açısına sahip oldukları saptanmıştır.

Sonuç: İlk ve acil yardım öğrencilerinin kadına yönelik şiddette geleneksel yaklaşım sergiledikleri ancak mesleki destekleyici rollerinde çağdaş bir yaklaşım gösterdikleri saptanmıştır. Bu sonuçlar doğrultusunda; öğrencilere mesleki bilgi ve becerinin kazandırılmasının yanı sıra kadına yönelik şiddet konusunda da farkındalık ve duyarlılık kazandırılması önerilmektedir.

Anahtar Kelimeler: Kadına yönelik şiddet, aile içi şiddet, mesleki rol, ilk ve acil yardım öğrencisi

\begin{abstract}
Objective: The research was carried out to determine the attitudes and effective factors of first and emergency students about their professional roles in violence and violence against women.

Methods: The sample of the cross-sectional study consisted of 240 students who attended the Arel University First and Emergency Aid Program and accepted to work. Data; The Demographic Information Form was collected using the Attitude Scale towards Violence and the Attitude Scale towards the Professional Roles of Health Care Professionals in Violence. Data; Percentage, number, mean, student $t$ test, one-way analysis of variance (ANOVA), kruskal-wallis, mann whitney $U$ and post hoc test / tamhane tests.

Results: It was found that female students and those whose father's education level is high school and above have a traditional attitude towards violence $(\mathrm{p}<0.05)$. A statistically significant difference was found between the students' desire to receive education about gender and violence $(\mathrm{p}=0.003)$ and between gender and reporting $(\mathrm{p}=0.024)$. When the general point average of the students' attitude towards violence scale (77.18 \pm 11.90$)$ and the attitude scale towards the professional roles of health personnel (59.30 \pm 8.08$)$ were examined, it was found that they had a traditional perspective that normalizes violence.

Conclusion: It has been determined that first aid and emergency aid students display a traditional approach to violence against women, but a contemporary approach in their professional supportive roles. In line with these results; In addition to providing students with professional knowledge and skills, it is recommended to raise awareness and sensitivity about violence against women. Keywords: Violence against women, domestic violence, professional role, first and first aid student
\end{abstract}

ORCID IDs of the authors: EŞ: 0000-0002-5971-2964; İGS: 0000-0002-9446-6148

Sorumlu yazar/Corresponding author: Doktora Öğrencisi Ezgi Şahin

İstanbul Üniversitesi-Cerrahpaşa Lisansüstü Eğitim Enstitüsü, Kadın Sağlığı ve Hastalıkları Hemşireliği Anabilim Dalı, İstanbul, TÜRKIYE

e-posta/e-mail: ezgishn90@gmail.com

Atıf/Citation: Şahin E, Satılmış Güngör İ. (2020). İlk ve acil yardım öğrencilerinin kadına yönelik şiddete ve şiddette mesleki rollerine iliş̧kin tutumları. Ordu Üniversitesi Hemşirelik Çalışmaları Dergisi, 3(2), 114-124.

DOI: $10.38108 /$ ouhcd.785559 


\section{Giriş}

Şiddet; kadınları sadece fiziksel olarak değil aynı zamanda, zihinsel, cinsel ve üreme sağlığ açısından da olumsuz etkileyen bir durumdur. Dünya Sağlık Örgütü (WHO) kadına yönelik şiddeti, toplumsal cinsiyet ayrımcılığına dayalı bir halk sağlığ 1 sorunu olarak tanımlamaktadır (WHO, 2017).

Kadına yönelik şiddetin nedenleri; sosyoekonomik düzeyin düşük olması, eşlerin ya da partnerlerin psikolojik sorunlar yaşaması, eşinin alkol kullanımı, erkek egemen bir ailede yetişmesi, şiddet içerikli film ve dizilerin izlenmesi, yakın çevrenin şiddeti normalleştirmesi, kadının şiddeti sadece fiziksel olarak algılaması gibi birçok faktör olabilmektedir. Kadınlar bu nedenlerden dolayı farklı şiddet türleriyle (fiziksel, cinsel, psikolojik ve ekonomik şiddet) karşı karşıya kalabilmektedir. Şiddet kadınlarda fiziksel ve ruhsal açıdan farklı düzeylerde olumsuzluklara neden olmaktadır. Yapılan bir çalışmada partner şiddetiyle karşılaşan kadınlar karşılaşmayanlara göre; 2 kat daha fazla depresyona ve madde kullanımına (alkol vb) eğilimlerinin olduğu, \%16 düşük doğum ağırlıklı bebeğe sahip oldukları, 1,5 kat daha fazla HIV'e yakalandıkları ve sifiliz, klamidya veya gonore enfeksiyonlarına yatkınlıklarının arttığı belirlenmiştir (Besser, 2005). Kadınların $\% 42$ 'si partnerinden fiziksel veya cinsel şiddet görmenin bir sonucu olarak yaralanmakta, küresel olarak rapor edilen kadın cinayetlerinin \%38'i partnerleri tarafından işlenmektedir (Besser, 2005).

Dünya Sağlı Örgütü (WHO) 2014 verilerine göre, hayatının herhangi bir döneminde partneri olan veya olmayan biri tarafından şiddete uğrayan kadın oranın \%35 olduğu belirtilmektedir (WHO, 2014). 2006 ile 2010 yılları arasındaki kadın cinayetlerin uluslararası sıralamasında, Amerika Birleşik Devletleri (ABD) 24., Fransa 68., Brezilya 7. sirada yer almaktadır (Waiselfisz, 2012; Silva ve ark., 2015). Türkiye'de yapılan Kadına Yönelik Şiddet Araştırması 2014 verilerine göre fiziksel şiddete maruz kalan kadın oranı \%36'dır (Ustaoğlu, 2015). Türkiye gibi Doğu kültürünün baskın olduğu Suriye, Pakistan,
Bangladeş ve Hindistan gibi ülkelerde töre, örf ve adetlerin getirdiği kurallar ve çevresel baskılardan ötürü, kadına karşı şiddettin bir kural olarak benimsendiği ve şiddetin sadece erkekler tarafından uygulanabileceği düşüncesi yer almaktadır. Ayrica aile ortamında bir disiplin yöntemi olarak algılanması, aile ve sosyal yaşamda meşru olarak algılanmasına, şiddetin sürekliliğine, gizlenmesine veya göz ard1 edilmesine yol açmaktadır (Toraman, 2015; Gharaibeh ve ark., 2012).

Şiddet, birçok açıdan kadın sağlığına zarar vermektedir. Şiddete maruz kalan çoğu kadın aile içinde yaşadiğ 1 şiddeti normalleştirerek hane halkı ile sınırlı tutmaktadır. Bu nedenle de kadınlar şiddeti sağlık hizmeti aramanın nedeni olarak açıklamamaktadır. Bu durumda sağlık profesyonellerinin şiddete maruz kalan kadınların belirlenmesinde, sorunun önlenmesi ve çözümlenmesinde önemli bir rolleri bulunmaktadır. $\mathrm{Bu}$ bağlamda sağlık profesyonellerinin duyarlı davranması ve şiddetin saptanması ve girişimini geciktirmeden yapması gerekmektedir. (WHO, 2017; Silva ve ark., 2015). Yapilan çalışmalarda, aile içi şiddete maruz kalan kadınların çoğunluğu hastane veya diğer sağlık kuruluşlarına başvurduklarında kendilerine aile içi şiddete maruz kalıp kalmadıklarının sorulmasını ve bu durumun ortaya çıkarılarak kendilerine yardım edilmesini istediğini belirtmiş̧lerdir (Chang ve ark., 2005; Hurley ve ark., 2005; Newman ve ark., 2005).

Şiddete maruz kalan kadınlara destek olabilmek için sağlık çalışanının özellikle aile içi şiddete karşı farkındalık kazanması gerekmektedir. $\mathrm{Bu}$ nedenle diğer sağlik profesyonelleri gibi ilk ve acil yardım öğrencilerinin kadına yönelik şiddet ile ilgili deneyimleri ve şiddette mesleki rollerine ilişkin tutumlarının belirlenmesinin, önemli olabileceği düşünülmektedir. Ancak yapılan çalışmalarda sağlık personelinin şiddete uğramış kadına nasıl yaklaşılması, ne tür sorular sorulması ve ne yapılması gerektiğini bilme konusunda bilgilerinin yetersiz olduğu vurgulanmaktadir (Toraman, 2015; Gharaibeh ve ark., 2012; Kaplan ve ark., 2014; Bozkurt ve ark., 2013). 
Ayrıca sağlık çalışanlarının şiddeti tanıma konusunda bilgi eksikliği ve deneyimsizliği birçok vakayı gözden kaçırmalarına neden olmaktadır (Gömbül, 2000).

Şiddete maruz kalan bireyle karşılaşan tüm sağlık çalışanlarının öncellikle şiddetin tanımını ve çeşitlerini, hangi durumların/olayların şiddet sayılacağı, şiddete uğrayan ve şiddeti uygulayan kişiye nasıl davranacağını bilmesi ve şiddeti önleme konusunda eğitilmeleri gerekmektedir. İlk ve Acil Yardım öğrencileri sağlık personeli içinde çoğu zaman hastayı ilk gören ve ilk müdahale uygulayan sağlık hizmeti sağlayıcısı olduğu için şiddet döngüsünün tanımlanmasında, buna müdahale etmede ve kadınların güvenliğinin sağlanmasında, yardım edebilecek önemli bir pozisyona sahiptir. Bu çalışma ilk ve acil yardım öğrencilerinin kadına yönelik şiddete ve şiddette mesleki rollerine ilişkin tutumlarını ve etkileyen faktörleri belirlemek amaciyla yapılmıştır.

\section{Yöntem}

Kesitsel olarak yapılan bu araştırmanın evrenini Arel Üniversitesi Meslek Yüksekokulu İlk ve Acil Yardım Programında okuyan 240 öğrenci oluşturmuştur. Eylül-Ekim 2019 tarihleri arasında aktif okula gelen 240 öğrenci ile çalışma tamamlanmıştır.

\section{Verilerin Toplanması}

Veriler literatür bilgileri doğrultusunda araştırmacı tarafından geliştirilen 21 sorudan oluşan Demografik Bilgi Formu (Karabulutlu, 2015; Kaplan ve ark., 2014; Gharaibeh ve ark., 2012; Connor ve ark., 2013; Sabuncuoğulları ve ark., 2016). Şiddete İlişkin Tutum Ölçeği ve Sağlık Personelinin Şiddette Mesleki Rollerine İlişkin Tutum Ölçeği ile toplanmıştır.

\section{Demografik Bilgi Formu}

Literatür doğrultusunda araştırmacı tarafindan oluşturulan bu form; öğrencilerin sosyo-demografik özellikleri ile kadına yönelik şiddette tutumlarını içeren 21 sorudan oluşmaktadır.

\section{Şiddete İlişkin Tutum Ölçeği (ŞITTÖ)}

Gömbül (2000) tarafindan geçerlik ve güvenirliği yapılan bu ölçekte aile içinde eşi tarafından kadına uygulanan şiddete ilişkin 19 madde yer almaktadır. 5 maddeli likert tipte bir ölçektir. Ölçeğin çalışmada kullanım amacı, öğrencilerin, şiddete maruz kalan kadına ilişkin tutumunu belirlemektir. Ölçek toplamından alınabilecek en düşük puan ortalaması 19, en yüksek puan ortalaması 95 'dir. Ölçekte toplam puanın yüksek olması, sağlık personelinin kadına ilişkin şiddet tutumunda geleneksel yaklaşımı, toplam puanının düşük olması ise modern ve çağdaş bir yaklaşımı benimsediklerini göstermektedir. Ölçek 4 alt boyuttan oluşup, toplam 19 maddeden oluşmaktadır. 19 sorunun 6's1 (7, 8, 10, 11, 12, 13. ifadeler) negatif yüklü maddelere karşılık gelmektedir. Gömbül'ün (2000) çalışmasında ölçeğin geçerlilik düzeyi .8233 bulunmuştur. $\mathrm{Bu}$ çalışmada ise ölçeğin Cronbach alfa katsayısı .63'dür.

Sağllk Personelinin Şiddette Mesleki Rollerine İlişkin Tutum Ölçeği (ŞMRITÖ)

Ölçek 5 maddeli likert tipte bir ölçek olup Gömbül (2000) tarafından geliştirilmiştir. Ölçeğin amacı sağlık personelinin şiddette mesleki rollerine ilişkin tutumunu belirlemektir (Gömbül, 2000; Kaplan ve ark., 2014; Bozkurt ve ark., 2013). Ölçekte sağlık personelinin destekleyici girişimlerine ait 6 madde; evliliği sürdürmeye ait 4 madde; evliliği sonlandırmaya ait 2 madde ve sağlık personelinin rolüne olumsuz bakışına ait 3 madde olmak üzere toplam 15 madde bulunmaktadır. Ölçekte ters madde bulunmaktadır $(7,8,12,13,14$ ve 15 . maddeler). Ölçek toplamında en düşük puan ortalaması 15, en yüksek puan ortalaması 75 'tir. Ölçekte toplam puanın yüksek olması, sağlık personelinin geleneksel yaklaşımı, toplam puanının düşük olması ise modern ve çağdaş görüşü benimsediklerini göstermektedir. Gömbül'ün (2000) çalışmasında ölçeğin geçerlilik düzeyi .7244 bulunmuştur. $\mathrm{Bu}$ çalışmada ise Cronbach alfa katsay1s1 .778'dir.

\section{Verilerin Analizi}

Çalışma SPSS 22.0 paket programında analiz edilmiştir. Sosyal Bilimlerde likert ölçek kullanımında genelde çalışmada kullanılacak 
verilerin normal dağılım göstermesi, çarpıklık ve basıklık değerlerinin \pm 3 arasında olmasına bağlıdır (Shao, 2002). Normal dağılım analizi sonucunda test edilen değişkenlere ait ortalama-medyanın birbirine yakın ve basıklık (ŞITÖ $=-.181$ ŞMRITÖ $=.015$ ) ile çarp $1 \mathrm{kl} 1 \mathrm{k}$ $($ ŞITÖ $=-.663$ ŞMRITÖ $=.646)$ değerlerinin normal dağılıma uygun olduğu belirlenmiştir. Tanımlayıcı istatistiklerden sayı, yüzdelik, ortalama ve standart sapma kullanılmıştır. Ölçek puanlarının çeşitli değişkenlere göre karşılaştırılmasında ise parametrik test koşullarında bağımsız t testi ve tek yönlü varyans analizi (ANOVA), bazı değişkenlerin karşılaştırılmasında (şiddete yönelik eğitim alma, şiddet olgusunda bildirim yapma ve cinsiyet) Ki-kare testi kullanılmıştır. Parametrik olmayan test koşullarında da Kruskal-Wallis ve Mann-Whitney testi kullanılmıştır. İkiden daha fazla grup arasındaki farkın hangi gruptan kaynaklandığını analiz etmek için Post Hoc test olarak Tamhane testi kullanılmıştır. İstatistiksel olarak $\mathrm{p}<0.05$ anlamlı kabul edilmiştir.

\section{Bulgular}

Çalışmada öğrencilerin yaş ortalaması 20.52'dir. Araştırmada öğrencilerin, \%50.8'inin k1z, \%52.1'inin ailesiyle yaşadıkları, \%53.3'ünün anne eğitim düzeyinin ilköğretim, 48.8'inin baba eğitim düzeyinin lise ve üzerinde olduğu, \%77.5'inin annesinin çalışmadığı, \%88.3'ünün babasının çalıştı̆ğ, $\% 62.5$ 'inin gelir düzeyinin orta düzeyde olduğu ve \%65.0'ının çekirdek aileye sahip oldukları belirlenmiştir.

Çalışmada kız öğrencilerin, baba eğitim düzeyi lise ve üzeri olanların, gelir durumu orta düzey olan öğrencilerin, şiddetin normal bir davranış olarak gören geleneksel bakıș açısına sahip oldukları bulunmuştur $(\mathrm{p}<0.05)$ (Tablo 1). Ayrıca kız öğrencilerin ve aile gelir durumu orta düzey olan öğrencilerin şiddette mesleki rollere ilişkin geleneksel bakış açısına sahip oldukları görülmektedir $(\mathrm{p}<0.05)$ (Tablo 1).

Tablo 1. Öğrencilerin bazı sosyo-demografik özelliklerine göre Şi̇TÖ ve ŞMRİTÖ puan ortalamalarının karşılaştırılması

\begin{tabular}{|c|c|c|c|c|}
\hline $\begin{array}{l}\text { Sosyo-Demografik } \\
\text { Özellikler }\end{array}$ & $\mathbf{n}$ & $\%$ & *ŞíTÖ Ort \pm SS & **ŞMRITÖÖ Ort \pm SS \\
\hline \multicolumn{5}{|l|}{ Cinsiyet } \\
\hline Kadın & 122 & 50.8 & $83.44 \pm 8.94$ & $61.55 \pm 7.23$ \\
\hline Erkek & 118 & 49.2 & $70.71 \pm 11.12$ & $56.98 \pm 8.28$ \\
\hline Test & & & $t=9.78 p<0.001$ & $t=4.56 p<0.001$ \\
\hline Babanızın eğitim durumu & & & Median(Min-Max) & Median(Min-Max) \\
\hline Okur/Yazar (mezun değil) & 24 & 10.0 & $75(49-95)$ & $58(39-70)$ \\
\hline İlköğretim & 99 & 41.3 & $81(42-95)$ & $61(38-72)$ \\
\hline Lise ve üzeri & 117 & 48.8 & $81(53-95)$ & $61(31-75)$ \\
\hline Test & & & $\mathrm{KW}=5.212 \mathrm{p}=0.022$ & $\mathrm{KW}=2.719 \mathrm{p}=0.099$ \\
\hline Ailenizin gelir durumunuz & & & Median(Min-Max) & Median(Min-Max) \\
\hline Düşük (Gelir< Gider) & 14 & 5.8 & $77(44-92)$ & $58(47-66)$ \\
\hline Orta (Gelir = Gider $)$ & 178 & 4.2 & $81(42-95)$ & $61(38-75)$ \\
\hline Yüksek (Gelir> Gider) & 48 & 0.0 & 77(50-93) & $58(31-71)$ \\
\hline Test & & & $\mathrm{KW}=5.573 \mathrm{p}=0.062$ & $K W=6.221 p=0.045$ \\
\hline
\end{tabular}


Öğrencilerin Şi̇TÖ ölçeği genel puan ortalamasına $(77.18 \pm 11.90)$ göre şiddete karş1 geleneksel bir tutum sergiledikleri saptanmıştır. Ölçeğin alt boyutları incelendiğinde ise öğrencilerin en fazla ekonomik şiddette $(28.50 \pm 6.06)$ geleneksel tutum sergiledikleri saptanmıştır (Tablo 2). ŞMRİTÖ ölçeği puan ortalaması $59.30 \pm 8.08$ olup, alt ölçek puan ortalamalarının dağılımı incelendiğinde, sağllk personelinin destekleyici girişimleri puan ortalaması $26.32 \pm 4.24$, evliliği
Her koşulda sürdürmeye yönelik puan ortalaması $14,46 \pm 3,33$, evliliği sonlandırmaya yönelik puan ortalaması $7.04 \pm 1.87$ ve şiddete ilişkin sağllk personelinin rolüne olumsuz bakıșa ait puan ortalaması $11.47 \pm 2.74$ olarak bulunmuştur (Tablo 2). Ölçeğin alt boyut puan ortalamaları incelendiğinde, sağlık personelinin destekleyici girişimleri puan ortalamasına (26.32 \pm 4.24$)$ göre kadına yönelik şiddette, mesleki rolüne ilişkin tutumunda geleneksel yaklaşım sergiledikleri belirlenmiştir (Tablo 2).

Tablo 2. Öğrencilerin ŞİTÖ ve ŞMRİTÖ puan ortalamasının dağılımı $(n=240)$

\begin{tabular}{|c|c|c|c|c|}
\hline Ölçekler & Ort & SS & Min-Max & $\begin{array}{c}\text { Ölçek Min-Max } \\
\text { Değerler }\end{array}$ \\
\hline ŞİTÖ & 77.18 & 11.90 & $42-95$ & $19-95$ \\
\hline Ekonomik Şiddet & 28.50 & 6.06 & $8-35$ & $7-35$ \\
\hline $\begin{array}{l}\text { Duygusal, Psikolojik, } \\
\text { Cinsel Şiddet }\end{array}$ & 23.93 & 4.74 & $6-30$ & $6-30$ \\
\hline $\begin{array}{l}\text { Meşrulaştırıcı } \\
\text { Mitler }\end{array}$ & 13.32 & 2.11 & $3-15$ & $3-15$ \\
\hline $\begin{array}{l}\text { Neden Açıklayıcı } \\
\text { Mitler }\end{array}$ & 11.41 & 2.55 & $3-15$ & $3-15$ \\
\hline ŞMRITÖ & 59.30 & 8.08 & $31-75$ & $15-75$ \\
\hline $\begin{array}{l}\text { Sağlık Personelinin } \\
\text { Destekleyici } \\
\text { Girişimleri }\end{array}$ & 26.32 & 4.24 & $6-30$ & $6-30$ \\
\hline Evliliği Sürdürme & 14.46 & 3.33 & $5-20$ & $4-20$ \\
\hline Evliliği Sonlandırma & 7.04 & 1.87 & $2-10$ & $2-10$ \\
\hline $\begin{array}{l}\text { Sağlık Personelinin } \\
\text { Rolüne Olumsuz Bakış1 }\end{array}$ & 11.47 & 2.74 & $3-15$ & $3-15$ \\
\hline
\end{tabular}

Öğrencilerin \%78.3’ü kadına yönelik şiddete ilişkin eğitim almak istediğini $(\mathrm{p}=0.006)$ \%84.6's1 meslek yaşamına geçtiklerinde kadına yönelik şiddet vakası ile karşılaştıkları zaman bildirim yapacağını $(\mathrm{p}<0.001)$ belirtirken aynı zaman da bu öğrencilerin şiddete karşı geleneksel bir yaklaşım gösterdikleri bulunmuştur (Tablo 3). Ayrıca şiddete ilişkin eğitim almak isteyen ve şiddet vakası ile karşılaştıkları zaman bildirim yapacağını belirten öğrencilerin şiddete uğramış kadına karşı mesleki rollerinde geleneksel yaklaşımı benimsedikleri saptanmıştır $(\mathrm{p}<0.001)$ (Tablo 3). 
Tablo 3. Öğrencilerin şiddete yönelik düşüncelerine göre ŞİTO ve SMRİTÖ puan ortalamalarının karşılaştırılması

\begin{tabular}{lcccc}
\hline Şiddete Yönelik Düşünceler & $\mathbf{n}$ & $\mathbf{\%}$ & ŞíTÖ & SMRİTÖ \\
\hline $\begin{array}{l}\text { Kadına yönelik şiddete ilişkin eğitim } \\
\text { llmak ister misiniz? }\end{array}$ & & & Ort \pm SS & Ort \pm SS \\
\hline Evet & 188 & 78.3 & $78.28 \pm 11.92$ & $60.22 \pm 7.86$ \\
\hline Hayır & 52 & 21.7 & $73.19 \pm 11.08$ & $55.98 \pm 8.04$ \\
\hline Test & & & $\mathrm{t}=2.768 \mathbf{p}=\mathbf{0 . 0 0 6}$ & $\mathrm{t}=3.430 \mathbf{p}=\mathbf{0 . 0 0 1}$
\end{tabular}

\begin{tabular}{|c|c|c|c|c|}
\hline Aile içinde şiddete tanık oldunuz mu? & & & & \\
\hline Evet & 86 & 35.8 & $77.10 \pm 12.40$ & $59.12 \pm 8.57$ \\
\hline Hayır & 154 & 64.2 & $77.22 \pm 11.66$ & $59.40 \pm 7.81$ \\
\hline Test & & & $\mathrm{t}=-.076 \mathrm{p}=0.939$ & $\mathrm{t}=-.258 \mathrm{p}=0,797$ \\
\hline $\begin{array}{l}\text { Meslek yaşamınızda kadına ilişkin } \\
\text { şiddet vakası ile karşılaşırsanız } \\
\text { bildirim yapar mısınız? }\end{array}$ & & & Median (Min-Max) & Median(Min-Max) \\
\hline Evet $^{1}$ & 203 & 84.6 & $81(42-95)$ & $62(38-75)$ \\
\hline Hayır $^{2}$ & 24 & 10.0 & $68(44-93)$ & $52(31-71)$ \\
\hline Şiddetin Özelliğine Göre ${ }^{3}$ & 13 & 5.4 & $74(45-86)$ & $53(39-66)$ \\
\hline Test & & & $\mathrm{KW}=18.90 \mathbf{p}<\mathbf{0 , 0 0 1}$ & $K W=25.80 \mathbf{p}<\mathbf{0 , 0 0 1}$ \\
\hline Post Hoc Test /Tamhane & & & $1>2 p=0.002$ & $1>2 \mathrm{p}=0.002$ \\
\hline
\end{tabular}

Öğrencilerin fiziksel ve ekonomik şiddete en çok baba (sırasıyla \%27.9; \%16.7), duygusal şiddete en çok arkadaş $(\% 45.8)$ ve sevgili $(\% 43.8)$, cinsel şiddete ise en çok sevgili $(\% 5.0)$ nedeniyle maruz kaldıkları tespit edilmiştir. Öğrencilerin anne (\%31.7), baba (\%35.4), abla/abi/kardeş (\%25.8), arkadaş $(\% 45.8)$ ve sevgiliden (\%43.8) sikl1kla duygusal şiddet gördükleri belirlenmiştir (Tablo 4).

K1z öğrencilerin \%86.1'i erkek öğrencilerin ise \%70.3'ü kadına yönelik şiddete ilişkin eğitim almak istediklerini belirtmektedir. Cinsiyet ile şiddete ilişkin eğitim alma isteği arasında istatistiksel olarak anlamlı bir ilişki saptanmıştır $\quad(p=0.003) \quad($ Tablo 5). Meslek hayatlarında şiddet vakası ile karşılaştıkları zaman k1z öğrencilerin \%90.2'si, erkek öğrencilerin ise \%78.8'inin resmi kuruluşlara bildirim yapacağ

Cinsiyet ile bildirim yapma arasinda istatistiksel olarak anlamlı bir ilişki saptanmıştır ( $\mathrm{p}=0.024)$ (Tablo 5).

\section{Tartışma}

Aile içi şiddete maruz kalan kadınların en çok başvurdukları yerlerden birisi acil servislerdir (Marshall ve Furr, 2010; McCauley ve ark., 1995; McLoughlin ve ark.,1993). Ancak kadınlar, özellikle şiddet uygulayan kişi/kişilerden korkmaları ve sağlık personelinden çekinmeleri, utanmaları gibi çeşitli nedenlerle şiddete uğradıklarını açıkça ifade edememektedir (Pakieser, ve ark., 1998). 
Tablo 4. Öğrencilerin yaşadıkları şiddet deneyimlerinin dağılımı

\begin{tabular}{lcccc}
\hline Şiddet Deneyimleri & \multicolumn{2}{c}{ Evet } & \multicolumn{2}{c}{ Hayır } \\
& n & \% & n & \% \\
\hline Anneden Şiddet & & & & \\
Fiziksel Şiddet & 22 & 9.2 & 218 & 90.8 \\
Duygusal Şiddet & 76 & $\mathbf{3 1 . 7}$ & 164 & 68.3 \\
Cinsel Şiddet & - & - & 240 & 100 \\
Ekonomik Şiddet & 15 & 6.3 & & \\
\hline Babadan Şiddet & & & & \\
\hline Fiziksel Şiddet & 67 & 27.9 & 173 & 72.1 \\
Duygusal Şiddet & 85 & $\mathbf{3 5 . 4}$ & 155 & 64.6 \\
Cinsel Şiddet & 1 & 0.4 & 239 & 99.6 \\
Ekonomik Şiddet & 40 & 16.7 & 200 & 83.3 \\
\hline Abla/Abi/Kardeşten & & & & \\
Şiddet & & & & \\
\hline Fiziksel Şiddet & 31 & 12.9 & 209 & 87.1 \\
Duygusal Şiddet & 62 & $\mathbf{2 5 . 8}$ & 178 & 74.2 \\
Cinsel Şiddet & - & - & 240 & 100 \\
Ekonomik Şiddet & 9 & 3.8 & 231 & 96.3 \\
\hline Arkadaştan Şiddet & & & & \\
\hline Fiziksel Şiddet & 40 & 16.7 & 200 & 83.3 \\
Duygusal Şiddet & 110 & $\mathbf{4 5 . 8}$ & 130 & 54.2 \\
Cinsel Şiddet & - & - & 240 & 100 \\
Ekonomik Şiddet & 2 & 0.8 & 238 & 99.2 \\
\hline Sevgiliden Şiddet & & & & \\
\hline Fiziksel Şiddet & 15 & 6.3 & 225 & 93.8 \\
Duygusal Şiddet & 105 & $\mathbf{4 3 . 8}$ & 135 & 56.3 \\
Cinsel Şiddet & 12 & 5.0 & 228 & 95.0 \\
Ekonomik Şiddet & 1 & 0.4 & 239 & 99.6 \\
\hline & & & &
\end{tabular}

Tablo 5. Öğrencilerin cinsiyetine göre eğitim alma ve şiddet vakası ile karşılaştıklarında bildirim yapma durumlarının dağılımı

\begin{tabular}{|c|c|c|c|c|c|}
\hline \multicolumn{6}{|c|}{ Cinsiyet } \\
\hline & \multicolumn{2}{|c|}{ Kadın } & \multicolumn{2}{|c|}{ Erkek } & \multirow[t]{2}{*}{ Test } \\
\hline & $\mathbf{n}$ & $\%$ & $\mathbf{n}$ & $\%$ & \\
\hline \multicolumn{6}{|c|}{$\begin{array}{l}\text { Şiddete ilişkin } \\
\text { eğitim alma isteği }\end{array}$} \\
\hline Evet & 105 & 86.1 & 83 & 70.3 & $\chi 2=8,741$ \\
\hline Hayır & 17 & 13.9 & 35 & 29.7 & $\mathrm{p}=\mathbf{0 . 0 0 3}$ \\
\hline \multicolumn{6}{|c|}{$\begin{array}{l}\text { Şiddet vakası le karşılaştığında } \\
\text { bildirim yapma durumu }\end{array}$} \\
\hline Evet & 110 & 90,2 & 93 & 78,8 & $\chi 2=5,088$ \\
\hline Hayır & 12 & 9,8 & 25 & 21,2 & $\mathbf{p}=\mathbf{0 . 0 2 4}$ \\
\hline
\end{tabular}

$\mathrm{Bu}$ nedenle ileride acil servislerde ve ambulanslarda görev yapacak ilk ve acil yardım bölümü öğrencilerinin, kadına yönelik şiddette ve şiddette mesleki rollere ilişkin farkındalık sahibi olması gerekmektedir.

Öğrencilerin şiddete ilişkin tutumlarını etkileyen önemli faktörlerden biri cinsiyet olarak belirtilmiştir. Kız öğrencilerin erkek öğrencilere göre kadına ilişkin şiddet tutumunda ve şiddette mesleki rollerinde şiddetin normal bir davranış olarak görüldüğü geleneksel bakış açısına sahip oldukları görülmektedir (Tablo 1). Çalışmamıza benzer olarak Kaplan ve ark. (2014) yaptıkları çalışmada k1z öğrencilerin erkek öğrencilere göre şiddeti meşrulaştıran geleneksel yaklaşım sergiledikleri belirtilmiştir. $\mathrm{Bu}$ durumda özellikle şiddete tanık olan k1z öğrenciler, annelerini rol model alarak partnerleri tarafindan kendilerine uygulanabilecek şiddet durumunu normalleştirerek kabullenme moduna girebilirler. Çünkü ülkemizde aile ortamında veya geniş aile yapılarında töre, örf ve adetlerin getirdiği kurallar ve çevresel baskılardan ötürü, kadına karşı şiddettin bir kural olarak benimsendiği ve şiddetin sadece erkekler tarafından uygulanabileceği düşüncesi yer almaktadır. Toplumumuzda ise kadına yönelik şiddette erkeklerin daha çok geleneksel tutuma, kadınların ise, şiddettin normalleştirilmediği ve toplumsal cinsiyet ayrımcılığının olmadığı daha modern ve çağdaş bir tutuma sahip olduğu bilinmektedir (Sabuncuoğulları ve ark., 2016; Dağlar ve ark., 2017; Kaplan ve ark., 2014). Cinsiyet faktörünün incelendiği diğer çalışmalarda da kadına yönelik şiddette erkek öğrencilerin kız öğrencilere göre daha geleneksel tutuma sahip olduğu saptanmıştır (Marshal ve Furr, 2010; Mandt, 1993; Dağlar ve ark., 2017; Agrawal ve Banerjee, 2010).

Bireylerde eğitim seviyesinin artmasıyla şiddetin normalleştirilmemesi beklenen bir durumdur. Ancak çalışmamızda baba eğitim düzeyi lise ve üzeri olan öğrencilerin de kadına karş1 şiddete ilişkin geleneksel bir yaklaşım gösterdikleri bulunmuştur ( $\mathrm{p}<0.05)$, (Tablo 1). $\mathrm{Bu}$ durum aile içi şiddet uygulandığına tanık olan erkek ögrrenciler rol model aldıkları 
babaları gibi partnerlerine şiddet eğilimi içine girebilirler. Şiddete tanık olan kız öğrenciler ise evlendiklerinde annelerini rol model alarak kendilerine uygulanacak şiddet durumunu teslimiyetçi bir anlayışla kabul edebilirler. Maalesef geleneksel aile yapısının her ne olursa olsun gelinliğinle gidersin, kefeninle çıkarsın gibi katı dogmatik anlayışı da, geleneksel tutumu ve kadına şiddeti tetiklemektedir. Çalışma bulgumuzun aksine Dağlar ve ark (2017) çalışmasında ise baba eğitim seviyesi yükseldikçe şiddete ilişkin tutumda geleneksellikten uzaklaşıldığı belirtilmiştir $(p<0.001)$. Çetinkaya'nın (2013) çalışmasında ise üniversite öğrencilerinin anne-baba eğitim durumuna göre şiddet eğilimleri açısından anlamlı bir farklılık bulunmamıştır. Çalışma sonuçlarının farklılı̆̆ı; yaşanılan yerin kırsal kesim ya da şehir olması, gelenek ve göreneklerin baskın olup olmaması, şiddete olan inanışlar, şiddete tanık ya da maruz olma durumu ve şiddetin algilanma şekli neden olabilir.

Şiddete ilişkin tutum ölçeği $(77.18 \pm 11.90)$ ve sağlık personellerinin mesleki rollerine ilişkin tutum ölçeği $(59.30 \pm 8.08)$ puan ortalaması incelendiğinde, öğrencilerin şiddet tutumlarında geleneksel yaklaşım sergiledikleri saptanmıştır. Benzer olarak; Suriye'de yapılan bir çalışmada, öğrencilerin \%18,4'ünün bazı durumlarda eş şiddetine karşı geleneksel bir tutum içinde olduğu belirtilmiştir (Gharaibeh ve ark., 2012; Sabancıoğulları ve ark., 2016). Bessette ve Peterson (2002)'un hemşirelik öğrencileri ile yaptıkları çalışmada ise, öğrencilerin çoğunluğunun kadına yönelik şiddette modern tutumu benimsediği görülmüştür. Kanbay ve ark. (2012) çalışmasında; öğrencilerin kadına yönelik şiddete ilişkin tutumlarının geleneksel eğilimde olduğu bulunmuştur. Çalışma bulgumuzun aksine, Dağlar ve ark. (2017) 'nın çalışmasında ise, öğrencilerin geleneksel bakış açısından uzaklaştıkları ve şiddete uğrayan kadını destekleyici çağdaş görüşe yaklaştıkları saptanmıştır. Connor ve ark (2013), yaptığı çalışmada ise hemşirelik öğrencilerinin şiddete karşı çağdaş ve modern bir tutuma sahip oldukları belirlenmiştir. Çalışmaların sonuçlarını öğrencilerin cinsiyeti, yaşadıkları bölge, aile ve çevre yapıları, anne-baba eğitim düzeyleri, gelir durumları ve şiddete tanık olma durumlarının etkilediği düşünülmektedir. Oysaki özellikle kadın sağlı̆̆ının korunmasında ve geliştirilmesinde önemli bir rolü olan sağlık profesyonellerinin şiddete karşı daha bilinçli ve duyarlı olup kendilerini bu alanda geliştirmeleri ve farkındalık kazanmaları gerekmektedir. Hatta kadına yönelik şiddetle mücadele ile ilişkili uygulamalarda görev almaları beklenmektedir.

Öğrencilerin 3/2'den fazlası şiddete ilişkin eğitim almak istemelerine rağmen (Tablo 3 ) kadına yönelik şiddette mesleki rollerinde geleneksel bakış açısına sahip oldukları saptanmıştır (26.32 \pm 4.24$)$ (Tablo 2). Benzer bulgu olarak Gömbül (2000) ve Kaplan ve ark. (2014) çalışmasında da öğrencilerin kadına yönelik şiddette mesleki rollerinde geleneksel bakış açısına sahip oldukları belirtilmektedir. Çalışma bulgumuzun aksine Bozkurt ve ark (2013) çalışmasında, öğrencilerin \%95.2'si ve Tunçel ve ark. (2007) çalışmasında da öğrencilerin \%68.9'u kadına ilişsin şiddette sağlık personelinin bilgilendirici ve destekleyici rolünü benimsemektedirler. Öğrencilerin, sağlık personelinin bilgilendirici ve destekleyici rolü benimsemelerinde; üniversitede aldıkları derslerin, bu dersler sırasında mesleki rollerinin farkına varmalarının ve derse giren öğretim elemanlarının kadına yönelik şiddete ilişkin modern ve çağdaş tutum sergilemelerinin etkili olduğu düşünülmektedir. Ayrıca öğrencilerin aile ve yetiştiği çevreden öğrendiği tutumlar da kadına yönelik şiddete bakış açısını etkileyebilmektedir. Mandt (1993) bireyin davranış değişikliğinin eğitim yoluyla gerçekleştiğini belirtmiştir. $\mathrm{Bu}$ nedenle öğrencilerin şiddet konusunda yeterli bilgi ve donanıma sahip olmaları ve bu konuda farkındalık geliştirmesi açısından ders müfredatlarında birinci sınıftan itibaren kadına yönelik şiddete ilişkin eğitim almalarının etkili olduğu düşünülmektedir

Öğrencilerin \%84.6's1 meslek yaşamların da şiddet vakası ile karşılaştıklarında bildirim yapacağını belirtirken aynı zamanda bu 
öğrencilerin şiddet tutumunda $(p<0.001)$ ve şiddette mesleki rollerinde $(\mathrm{p}<0.001)$ geleneksel bakış açısına sahip oldukları saptanmıştır. Günal (2016)'ın çalışmasında öğrencilerin meslek yaşamında kadına yönelik şiddet olgusu veya şüphesi ile karşılaşmaları durumunda bildirim yapıp yapmayacaklarına göre ŞİTÖ toplam puan ortalamaları arasında istatistiksel olarak anlamlı fark saptanmıştır ( $p<0.001)$. Çalışmamızda öğrencilerin 3/1'inin aile içinde şiddete tanık olduğu saptanmıştır Karabulutlu (2015) çalışmasında, öğrencilerin $\% 29.1$ 'i aile içi şiddete tanık olduğunu belirtmiştir. Öğrencilerin şiddete tanık oldukları ve meslek hayatında da karşılaştıkları zaman bildirim yapacaklarını belirttikleri halde şiddeti normalleştirmeleri; şiddeti sadece fiziksel boyutta değerlendikleri, ekonomik, duygusal, psikolojik ve cinsel şiddeti meşrulaştırmalarından dolayı sonuçlarının farkında olmadıkları düşünülmektedir. Örneğin yapılan bir çalışmada kadınların cinsel şiddeti şiddet olarak görmedikleri ve bunu belirtmedikleri ifade edilmektedir (Güler ve ark., 2005).

Öğrencilerin yaklaşık 3/2'si en fazla duygusal ve fiziksel şiddete maruz kaldıklarını ifade etmişlerdir. Öğrencilerin duygusal şiddeti en çok arkadaş ( $\% 45.8)$ ve sevgiliden (\%43.8), fiziksel şiddeti ise baba ve arkadaştan gördüğü saptanmıştır. Karabulutlu (2015) çalışmasında, öğrencilerin fiziksel şiddete (\%95) aile içinde, duygusal şiddete $(\% 52)$ partnerleri tarafından maruz kaldıklarını, Kanbay ve ark. (2012) çalışmasında ise öğrencilerin en çok (\% 44.1) ailesi tarafından şiddet gördüğünü ifade etmiştir. $\mathrm{Bu}$ sonuçlar 1şı̆̆ında, şiddet olaylarının giderek arttı̆gı günümüzde, öğrencilerin şiddetle karşılaşma olasıllğının yüksek olduğunu düşündürmektedir.

$\mathrm{Bu}$ çalışmada kız öğrencilerin erkek öğrencilere göre kadına ilişkin şiddet tutumunda ve şiddette mesleki rollerinde geleneksel bakış açısına sahip oldukları belirtilse de (Tablo 1), k1z öğrencilerin (\%86.1) erkek öğrencilere (\%70.3) göre daha yüksek oranda kadına yönelik şiddete ilişkin eğitim almak istedikleri belirlenmiştir. Bu durum kız öğrencilerin, erkek öğrencilere göre şiddeti meşrulaştıran geleneksel bir aile ve çevre yapısıyla yetişmiş olmasıyla ilişkilendirilebilir. Cinsiyet ile şiddete ilişkin eğitim alma isteği arasında istatistiksel olarak anlamlı bir fark saptanmıştır $(\mathrm{p}=0.003)$. Meslek hayatlarında şiddet vakası ile karşılaştıkları zaman kız öğrencilerin (\%90.2) erkek öğrencilere $(\% 78.8)$ göre daha yüksek oranda resmi kuruluşlara bildirim yapacağı belirtilirken, cinsiyet ile bildirim yapma arasinda istatistiksel olarak anlaml bir fark bulunmuştur ( $\mathrm{p}=0.024)$ (Tablo 5). Ancak erkek öğrencilerin, k1z öğrencilere göre daha düşük oranda bildirim yapma isteği, aile içi şiddeti, problemlerin çözümünde bir araç olarak algılanmasıyla ilişkilendirilebilir. Cinsiyet karşılaştırması diğer araştırmalarda rastlanılmadığı için benzer ya da farklı bulgular belirtilememiştir.

\section{Sonuç ve Öneriler}

Öğrencilerin cinsiyeti, gelir düzeyleri, baba eğitim düzeyi, şiddete ilişkin eğitim alma isteği ve şiddet vakasinda bildirim yapma durumu kadına yönelik şiddete ve şiddette mesleki rollerine ilişkin tutumlarını etkilemektedir. Kadına yönelik şiddete ilişkin hiçbir eğitim almadıkları saptanan öğrencilerin bunun farkında olup eğitim almaya istekli olmaları da bu konunun öneminin farkında olduklarını göstermektedir. Çalışma sonucunda; ilk ve acil yardım öğrencilerinin kadına yönelik şiddet tutumunda ve şiddette mesleki rollerinde şiddetin normalleştirilmesini kabul eden geleneksel bakış açısına sahip oldukları belirtilmiştir. Benzer sonuçların fazla olmasından ötürü üniversitelerin müfredat programlarına şiddet ve toplumsal cinsiyet konularının eklenmesi ya da ayrı derslerin açılması önerilebilir. Üniversite eğitim düzeyinde hala geleneksel tutuma sahip olan öğrencilerin olması, öğrencilere mesleki bilgi ve becerinin kazandırılmasının yanı sıra kadına yönelik şiddet konusunda da farkındalık ve duyarlılık kazandırılması gerekliliğini ortaya koymaktadır. Öğrencilerin kadına yönelik şiddet konusunda eğitim almaları, gelecekteki 
mesleki rolleriyle tutumlarının geliştirilmesine katkı sağlayacağı ve şiddete maruz kalan kadınlara çözüm yolları arayarak gerekli duygusal ve sosyal destek vereceği düşünülmektedir. Şiddet konusunda duyarlılığın ve farkındalığın artırılması için kitle iletişim araçları ve medyanın daha etkin kullanılması ve sağlık politikalarını hazırlayan karar vericilerin; sağlık personeline yönelik farkındalık, bilgi, eğitim ve iletişim ağları oluşturmada öncülük etmeleri önerilmektedir. Ayrıca sağlık personellerinin şiddet vakası ile karşılaştıklarında gerekli kuruluşlara bildirim yapmak üzere vaka tanılama ya da anamnez formlarında şiddetin önemli belirtilerine ilişkin soruların yer alması önerilebilir.

\section{Teșekkür}

Araştırmaya katılan öğrencilere teşekkür ederiz.

Araştırmanın Etik Yönü/ Ethics Committee Approval: Araştırmaya başlamadan önce kurumdan etik kurul izni (2019/03) alınmıştır. Ayrıca çalışmayı kabul eden öğrencilerden Helsinki Deklerasyonu Prensipleri'ne uygun olarak bilgilendirilmiş onamları yazılı ve sözlü olarak alınmıştır.

Hakem/Peer-review: D1ş hakem değerlendirmesi.

Yazar Katkısı/Author Contributions: EŞ, İG; Fikir/kavram: EŞ, İG; Tasarım: EŞ, İG; Danışmanlık: EŞ, İG; Veri toplama ve/veya Veri İşlem: EŞ; Analiz ve/veya Yorum:EŞ,İG; Kaynak tarama:EŞ; .Makalenin Yazımı:EŞ, İG; Eleştirel inceleme:EŞ,İG

Çıkar çatışması/Conflict of interest: Yazarlar arasında herhangi bir çıkar çatışması söz konusu değildir.

Finansal Destek/Financial Disclosure: Finansal destek alınmamıştır.

\section{Çalışma Literatüre Ne Kattı?}

- Araştırma kapsamına alınan üniversite öğrencileri şiddet konusunda geleneksel yaklaşım sergilemişlerdir.

- Öğrenciler şiddete maruz kalan kadına karşı danışmanlık yapabilmek için şiddet konusunda eğitim almaya isteklidir.

- Öğrenciler tarafından kadına yönelik şiddetin önemli bir halk sağlığı sorunu olarak görüldüğü, kadın sağllğının korunmasında ve geliştirilmesinde sorumluluklarının da olduğu konusunda farkındalık kazanmışlardır.

\section{Kaynaklar}

Agrawal S, Banerjee A. (2010). Perception of violence against women among future health professionals in an Industrial Township. Industiral Psychiatry Journal, 19(2), 90-93.

Baysan L. (2006). Hemşire ve ebelerin kadına yönelik şiddet belirtilerini tanımalarına ilişkin ölçek geliştirme. Sağlık ve Toplum Dergisi, 16(2), 101-112.

Besser A. (2005). The apple does not fall far from the tree: attachment styles and personality vulnerabilities to depression in three generations of women. Personal Soc Psychol Bull, 31(8), 1052-1073.

Bessette HD, Peterson SS. (2002). Attitudes of adult nurse practitioner students toward women experiencing domestic violence. Journal of Nursing Education, 41(5), 27-30.

Bozkurt ÖD, Daşıkan Z, Kavlak O, Şirin A. (2013). Ebelik Öğrencilerinin gebelikte şiddet konusundaki bilgi, görüş ve mesleki tutumlarının belirlenmesi. Balıkesir Sağlık Bilimleri Dergisi, 2(2), 99-107.

Connor P. Nouer S. Speck P. Mackey S. Tipton NG. (2013). Nursing students and intimate partner violence education: improving and integrating knowledge into health care curricula. Journal of Professional Nursing, 29(4), 233-239.

Çelik AS, Türkoğlu N, Apay SE, Aydın A, Pasinlioğlu T. (2015). Ebe ve hemşirelere verilen eğitimin kadına yönelik aile içi şiddete ilişkin tutumlarına etkisi. Sağlık Bilimleri ve Meslekleri Dergisi, 2(2), 138- 148.

Çetinkaya SK. (2013). Üniversite öğrencilerinin şiddet eğilimlerinin ve toplumsal cinsiyet rollerine ilişkin tutumlarının incelenmesi, Nesne Psikoloji Dergisi, 1(2), 21-43.

Chang JC, Cluss PA, Ranieri L et al. (2005). Health care interventions for intimate partner violence: what women want. Womens Health Issues, 15(1), 21-30.

Dağlar G, Bilgic D, Demirel G. (2017). Ebelik ve hemşirelik öğrencilerinin kadına yönelik şiddete ilișkin tutumları. Dokuz Eylül Üniversitesi Hemşirelik Fakültesi Dergisi, 10(4), 220-228.

Hurley KF, Brown-Maher T, Campbell SG et al. (2005). Emergency department patients' opinions of screening for intimate partner violence among women. Emergency Medicine Journal, 22(2), 97-98. 
Gharaibeh MK, Abu-Baker NN, Aji S. (2012). Attitudes toward and justification for wife abuse among Syrian medical and nursing students. Journal of Transcultural Nursing, 23(3), 297305.

Gömbül Ö. (2000). Hemşirelerin ailede kadına esi tarafindan uygulanan şiddete ve şiddette mesleki role ilişkin tutumları. Hemşirelik Araştırma Dergisi, 1, 19-32.

Güler N, Tel H, Tuncay F.Ö. Kadının Aile İçinde Yaşanan Şiddete Bakışı, Cumhuriyet Üniversitesi Tıp Fakültesi Dergisi, 2005, 27 (2), 51- 56.

Kanbay Y, Işık E, Yavuzaslan M, Keleş S. (2012). Hemşirelik öğrencilerinin kadına yönelik aile içi şiddetle ilgili görüş ve tutumlarının belirlenmesi. Gümüşhane Üniversitesi Sağl1k Bilimleri Dergisi, 1(2), 107-119.

Kaplan S, Akalın A, Pınar G, Yilmazer T. (2014). Hemşirelik öğrencilerinin kadına yönelik aile içi şiddet ve aile içi şiddette mesleki rollerine ilişkin tutumları. Yıldırım Beyazıt Üniversitesi Sağlık Bilimleri Fakültesi Hemşirelik E-Dergisi, 2(1), 26-35.

Karabulutlu Ö. (2015). Hemşirelik öğrencilerinin kadına yönelik aile içi şiddete ilişkin deneyimleri ve tutumları. Cumhuriyet Hemşirelik Dergisi, 4(1), 27-34.

Mandt AK. (1993). Cirriculum revolution in action: nursing and crisis intervention for victims of family violence. Journal of Nursing Education, 32(1), 7-12.

Marshall GA, Furr LA. (2010). Factors that affect women's attitudes toward domestic violence in Turkey. Violence and Victim, 25(2), 265-277.

McCauley J, Kern DE, Kolodner K, Dereotu L, Schroeder AF, DeChant HK, et al. (1995). The "battering syndrome": prevalence and clinical characteristics of domestic violence in primary care internal medicine practices. Annals of Internal Medicine, 123, 737-746.

McLoughlin E, Lee D, Letellier P. (1993). Emergency department response to domestic violence-California. Journal of the American Medical Association, 42(32), 617-620.

Newman JD, Sheehan KM, Powell EC. (2005). Screening for intimate partner violence in the pediatric emergency department. Pediatric Emergency Care, 21(2), 79-83.
Pakieser RA, Lenaghan PA, Muelleman RA. (1998). Battered women: where they go for help. Journal of Emergency Nursing, 24(1), 1619.

Sabancıoğulları S, Taşkın FY, Ar E, Çakmaktepe G. (2016). Hemşirelik öğrencilerinin kadına yönelik şiddete ve şiddette mesleki role ilişkin tutumları, benlik saygıları ve etkileyen faktörler. Hemşirelikte Eğitim ve Araştırma Dergisi, 13(1), 35-43.

Shao AT. (2002). Marketing Research: An Aid to Decision Making, Cincinnati, Ohio: SouthWestern/Thomson Learning.

Silva CD, Oliveira Gomes VL, Oliveira DC, Marques SC, Fonseca AD, Martins SR. (2015). Social representation of domestic violence against women among Nursing Technicians and Community Agents. Revista da Escola de Enfermagem Da USP, 49(1), 22-29.

Toraman AU. (2015). Identi cation of intimate partner violence in health care settings: Why health care providers ask (or don't) about intimate partner violence? Turkiye Klinikleri Journal of Public Health Nurs-Special Topics, 1(2), 12-18.

Tunçel EK, Dündar C, Peşker Y. (2007). Ebelik ve Hemşirelik Öğrencilerinin Aile İçi Şiddet Konusunda Bilgi ve Tutumlarının Değerlendirilmesi. Genel Tıp Dergisi, 17(2), 105-110.

Ustaoğlu A. (2015). Türkiye'de Kadına Yönelik Aile İçi Şiddet Araştırması. Hacettepe Üniversitesi Nüfus Etütleri Enstitüsü, 83-84 Erişim yeri: http://www.hips.hacettepe.edu.tr/ KKSA-TRAnaRaporKitap26Mart.pdf

Waiselfisz JJ. (2012). Mapa da violência. Atualização: homicídio de mulheres no Brasil. Cebela; Flacso-Brasil. http://mapadaviolencia.org.br/pdf2012/MapaVi olencia2012_atual_mulheres.pdf

World Health Organization. Intimate partner and sexual VAW. 2017 Retrived from: http://www.who.int/mediacentre/factsheets/fs23 9/en/ Accessed: 06.04.2018 